\title{
Synthesis of $\alpha-\mathrm{Fe}_{2} \mathrm{O}_{3}$ and Fe-Mn Oxide Foams with Highly Tunable Magnetic Properties by the Replication Method from Polyurethane Templates
}

\author{
Yuping Feng ${ }^{1,2}$, Jordina Fornell ${ }^{1, *}$, Huiyan Zhang ${ }^{1}$, Pau Solsona ${ }^{1}$, Maria Dolors Baró ${ }^{1}$, \\ Santiago Suriñach ${ }^{1}$, Eva Pellicer ${ }^{1}$ (D) and Jordi Sort ${ }^{1,3}$ \\ 1 Departament de Física, Universitat Autònoma de Barcelona, E-08193 Bellaterra, \\ Cerdanyola del Vallès, Spain; fengyupingcsu@gmail.com (Y.F.); abuzhang1984@gmail.com (H.Z.); \\ Pau.Solsona@uab.cat (P.S.); dolors.baro@uab.es (M.D.B.); Santiago.Surinyach@uab.cat (S.S.); \\ eva.pellicer@uab.cat (E.P.); jordi.sort@uab.cat (J.S.) \\ 2 State Key Laboratory of Optoelectronic Materials and Technologies, School of Electronics and Information \\ Technology, Sun Yat-Sen University, Guangzhou 510275, China \\ 3 Institució Catalana de Recerca i Estudis Avançats (ICREA), Pg. Lluís Companys 23, E-08010 Barcelona, Spain \\ * Correspondence: jordina.fornell@uab.cat; Tel.: +34-935-811-401
}

Received: 17 January 2018; Accepted: 10 February 2018; Published: 11 February 2018

\begin{abstract}
Open cell foams consisting of Fe and Fe-Mn oxides are prepared from metallic Fe and Mn powder precursors by the replication method using porous polyurethane (PU) templates. First, reticulated PU templates are coated by slurry impregnation. The templates are then thermally removed at $260{ }^{\circ} \mathrm{C}$ and the debinded powders are sintered at $1000{ }^{\circ} \mathrm{C}$ under $\mathrm{N}_{2}$ atmosphere. The morphology, structure, and magnetic properties are studied by scanning electron microscopy, X-ray diffraction and vibrating sample magnetometry, respectively. The obtained Fe and Fe-Mn oxide foams possess both high surface area and homogeneous open-cell structure. Hematite $\left(\alpha-\mathrm{Fe}_{2} \mathrm{O}_{3}\right)$ foams are obtained from the metallic iron slurry independently of the $\mathrm{N}_{2}$ flow. In contrast, the microstructure of the FeMn-based oxide foams can be tailored by adjusting the $\mathrm{N}_{2}$ flow. While the main phases for a $\mathrm{N}_{2}$ flow rate of $180 \mathrm{~L} / \mathrm{h}$ are $\alpha-\mathrm{Fe}_{2} \mathrm{O}_{3}$ and $\mathrm{FeMnO}_{3}$, the predominant phase for high $\mathrm{N}_{2}$ flow rates (e.g., $650 \mathrm{~L} / \mathrm{h}$ ) is $\mathrm{Fe}_{2} \mathrm{MnO}_{4}$. Accordingly, a linear magnetization versus field behavior is observed for the hematite foams, while clear hysteresis loops are obtained for the $\mathrm{Fe}_{2} \mathrm{MnO}_{4}$ foams. Actually, the saturation magnetization of the foams containing $\mathrm{Mn}$ increases from $5 \mathrm{emu} / \mathrm{g}$ to $52 \mathrm{emu} / \mathrm{g}$ when the $\mathrm{N}_{2}$ flow rate (i.e., the amount of $\mathrm{Fe}_{2} \mathrm{MnO}_{4}$ ) is increased. The obtained foams are appealing for a wide range of applications, such as electromagnetic absorbers, catalysts supports, thermal and acoustic insulation systems or wirelessly magnetically-guided porous objects in fluids.
\end{abstract}

Keywords: porous inorganic oxide foams; manganese ferrite; Iron oxide; replication processing; magnetic properties

\section{Introduction}

Reticulated sponges made of polyurethane (PU) have been commercially available since the 1950s [1]. The first attempts to transfer porous templates into ceramic (i.e., oxide) foams by the powder slurry replication method date from early 1960s [2]. At present, the method has become widely available for many applications involving porous oxide materials: electromagnetic wave absorbers, gas sensors, catalysts, oil-water separators and lithium-ion batteries [3-8]. As a consequence, the polymeric sponge replication process has consolidated as a promising technique to create cellular oxide structures with 3D interconnected pores, characterized by high strength and high corrosion resistance in acid and alkaline media [9-11]. In the 1970s, metallic foams also started to be prepared 
by this method and they found applications such as battery electrodes, catalysts or filters [12-14]. Over the past ten years, the replication method has been extended to manufacture porous steels [15-18] and porous Cu-based [19] and Ti-based alloys [20,21].

While many studies have focused on metallic foams [15-21], fewer efforts have been devoted to synthesizing inorganic oxide foams through the polymer sponge replication process [22]. So far, to the best of our knowledge, the possibility to use this technique to produce oxide foams with magnetic properties has not been explored.

Manganese ferrite $\left(\mathrm{MnFe}_{2} \mathrm{O}_{4}\right)$ is a well-known ceramic compound with electrically insulating and soft ferrimagnetic properties at room temperature. It has been widely used in the electronics industry to fabricate magnetic cores for read/write heads for high-speed tape or hard disk recording $[23,24]$. More recently, $\mathrm{MnFe}_{2} \mathrm{O}_{4}$ has emerged as a promising material to be used as a catalyst $[25,26]$, in hydrogen production technologies [24] or for oil-water separation [7]. Diverse preparation techniques, such as high energy ball milling [24,27], co-precipitation [28,29] or sol-gel routes [30], have been used to obtain $\mathrm{MnFe}_{2} \mathrm{O}_{4}$ powders and nanoparticles. However, the preparation of porous $\mathrm{MnFe}_{2} \mathrm{O}_{4}$ remains challenging and rather elusive.

Meanwhile, magnetic foams made of $\mathrm{Fe}_{2} \mathrm{O}_{3}, \mathrm{Fe}_{3} \mathrm{O}_{4}$, $\mathrm{Co}$ or $\mathrm{Ni}$ are appealing since they combine the intrinsic properties of magnetic materials with the aforementioned advantages of the porous structures, constituting magnetic materials with high surface area, low density and high strength-to-weight ratio. For instance, ultralight $\mathrm{Fe}_{2} \mathrm{O}_{3} / \mathrm{C}$ foams produced using polyelectrolyte-grafted PU sponges [7] exhibit one of the highest oil-absorption capacities among the reported counterparts. Magnetic $\mathrm{Fe}_{3} \mathrm{O}_{4}$ nanoparticles/PU composites produced by in-situ blending methods have also been reported as good candidates for wastewater treatments, acting as carriers for immobilized microorganisms [30].

Therefore, the aim of the present work is to use the replication method to produce Fe and Fe-Mn oxides open-cell porous structures. The magnetic behavior of the foams is tuned, first, by the composition of the metallic slurry precursor and, secondly, by adjusting the $\mathrm{N}_{2}$ flow. The influence of the $\mathrm{N}_{2}$ flow and the Mn content, as well as the synergistic effect of porosity and magnetism are investigated.

\section{Materials and Methods}

Commercial Fe (97\%) and Mn (99\%) powders were used to coat a reticulated PU sponge by the impregnation method. First, the powders were mixed and mechanically milled in a planetary mill device (Fritsch Pulverisette 5, Fritsch, Idar-Oberstein, Germany) to reduce the powder size and to obtain the targeted composition, Fe or Fe-30Mn (Fe:Mn ratio of 70:30 nominal wt \%). The raw powders were milled under Ar atmosphere with a ball-to-powder weight ratio of 10:1 at $300 \mathrm{rpm}$ for $15 \mathrm{~h}$. The particle size of the as-milled powders, calculated from a Scanning Electron Microscopy (SEM) image using the ImageJ software, was $10.8 \pm 1.4 \mathrm{~mm}$. To prepare the slurry, the milled powders were mixed with poly(ethylene glycol) (PEG) and distilled water. PEG acted as a binder and was used to control the slurry viscosity and to favor the adhesion of the powder particles to the sponge before sintering. The composition of the slurry is listed in Table 1 . Subsequently, $1 \mathrm{~cm}^{3}$ of a commercial reticulated PU sponge, acting as organic template, was immersed into the slurry for $5 \mathrm{~min}$ to allow complete impregnation. The sponge was removed from the suspension and was squeezed to ensure that only a thin layer of slurry covered the skeleton of the PU template without blocking the pores. Then, the impregnated template was dried at room temperature for at least $12 \mathrm{~h}$ before sintering. Finally, the template was thermally removed at $260^{\circ} \mathrm{C}$ and the debinded powders were sintered in a tubular furnace (Carbolite MTF 9/15, Parsons Lane, UK) at $1000{ }^{\circ} \mathrm{C}$ for $2 \mathrm{~h}$ under $\mathrm{N}_{2}$ flow ranging from 180 to $650 \mathrm{~L} / \mathrm{h}$. 
Table 1. Components and mass percentages of the slurry.

\begin{tabular}{cccc}
\hline Components & Fe or Fe 30Mn & Binder & Distilled Water \\
\hline Mass percent $(\%)$ & 50 & 17 & 33 \\
\hline
\end{tabular}

SEM observations were done on a Zeiss Merlin microscope (Carl Zeiss Microscopy, Jena, Germany) equipped with an energy dispersive X-ray (EDX) spectroscopy detector (Oxford Instruments, Abingdon, UK) for compositional analyses. X-ray diffraction (XRD) was carried out on a Philips X'Pert diffractometer (Philips, Amsterdam, The Netherlands) using $\mathrm{Cu} \mathrm{K} \mathrm{K}_{\alpha}$ radiation. The measurements were performed in the angular range $2 \theta=30-100^{\circ}$ with a step size of $0.026^{\circ}$. Furthermore, Rietveld refinement of the XRD patterns using the X'Pert HighScore Plus software (PANalytical, Almelo, The Netherlands) was carried out to determine the cell parameters and the percentage of the constituent phases.

Hysteresis loops were recorded at room temperature using a vibrating sample magnetometer (VSM) from MicroSense (LOT-QuantumDesign, Darmstadt, Germany), with a maximum applied magnetic field of $20 \mathrm{kOe}$.

\section{Results and Discussion}

\subsection{Microstructure and Compositional Analyses}

Figure 1 shows SEM images of the sintered open cell foams obtained by the replication process from Fe- (Figure 1a) and FeMn- (Figure 1b-d) containing slurries. At a first glance, a rather homogeneous pore distribution can be observed, with pore sizes of the order of $400 \mu \mathrm{m}$. Fully-compact pore walls were observed in the foams produced from the Fe- and FeMn-containing slurries obtained at the lowest $\mathrm{N}_{2}$ flow (Figure 1a,b); however, at larger $\mathrm{N}_{2}$ flows, the pore walls exhibit a nanoporous morphology although the distribution and the size of the big pores was not compromised. The composition of the foams obtained at different nitrogen flow rates, measured by energy-dispersive $\mathrm{X}$-ray (EDX) analyses, is listed in Table 2. An O/Fe ratio of 1.56 is calculated for the foam produced from the Fe-containing slurry, suggesting the formation of $\mathrm{Fe}_{2} \mathrm{O}_{3}$. It is worth mentioning that no changes were observed in the foams produced under larger $\mathrm{N}_{2}$ flow (such as $350 \mathrm{~L} / \mathrm{h}$ and $650 \mathrm{~L} / \mathrm{h}$ ) from the Fe-containing slurry in terms of pore morphology, integrity of the foam or chemical composition (not shown in the manuscript). However, the foams produced at open atmosphere were more powdery and brittle. In contrast, compositional changes were observed in the foams produced from the FeMn-containing slurry when changing the $\mathrm{N}_{2}$ flow. For the foam produced at $180 \mathrm{~L} / \mathrm{h}$, the $\mathrm{O} / \mathrm{Fe}(\mathrm{Mn})$ ratio is 1.5 suggesting the formation of $\mathrm{Fe}_{2} \mathrm{O}_{3}$ or $\mathrm{FeMnO}_{3}$. Conversely, the $\mathrm{O} / \mathrm{Fe}(\mathrm{Mn})$ ratio decreases to 1.38 and 1.27 as the $\mathrm{N}_{2}$ flow is increased to $350 \mathrm{~L} / \mathrm{h}$ and $650 \mathrm{~L} / \mathrm{h}$, respectively, hence suggesting the formation of $\mathrm{Fe}_{3-x}(\mathrm{Mn})_{x} \mathrm{O}_{4}$.

Table 2. Energy dispersive X-ray (EDX) composition of the foams produced from the Fe-containing slurry at a $\mathrm{N}_{2}$ flow of $180 \mathrm{~L} / \mathrm{h}$ and from the FeMn-containing slurry at a $\mathrm{N}_{2}$ flow of 180,350 and $650 \mathrm{~L} / \mathrm{h}$.

\begin{tabular}{cccc}
\hline Sample & Mn (at \%) & Fe (at \%) & O (at \%) \\
\hline Fe-O (180 L/h) & 0 & 39 & 61 \\
Fe-Mn-O (180 L/h) & 12 & 28 & 60 \\
Fe-Mn-O (350 L/h) & 16 & 26 & 58 \\
Fe-Mn-O (650 L/h) & 18 & 24 & 56 \\
\hline
\end{tabular}



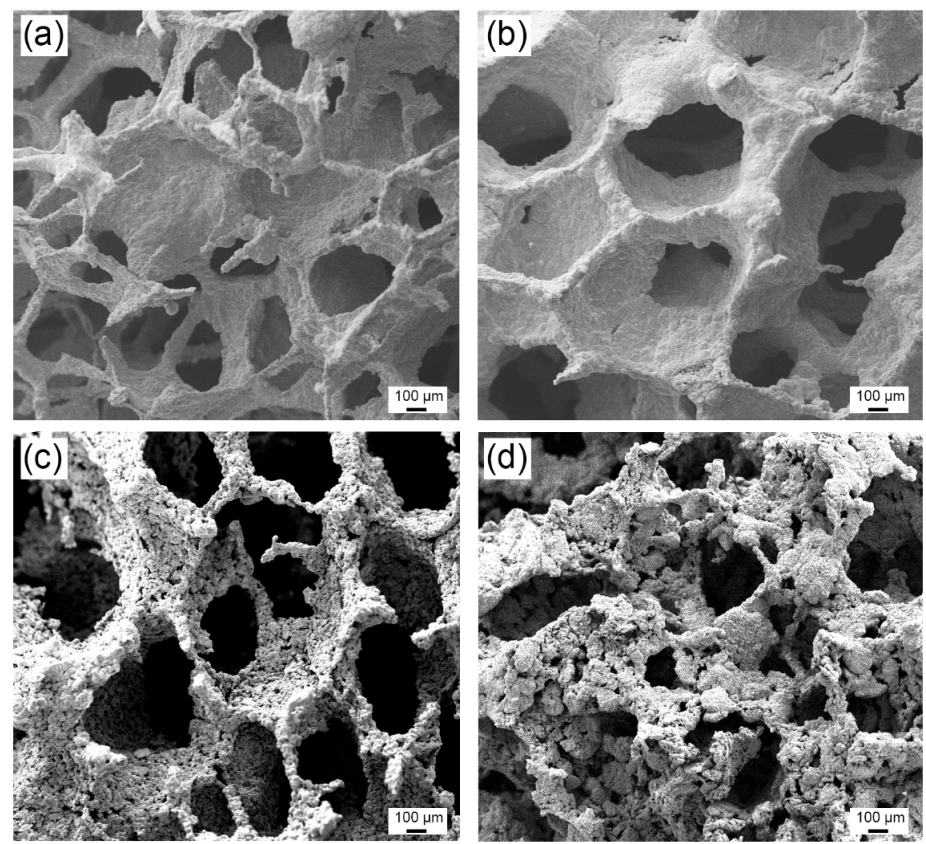

Figure 1. (a) SEM image of a Fe-O foam prepared at a nitrogen flow rate of $180 \mathrm{~L} / \mathrm{min}$. SEM image of Fe-Mn-O foams prepared under a nitrogen flow rate of (b) $180 \mathrm{~L} / \mathrm{h},(\mathbf{c}) 350 \mathrm{~L} / \mathrm{h}$ and (d) $650 \mathrm{~L} / \mathrm{h}$.

To shed light on the microstructure of the open-cell foams X-ray diffraction was carried out (Figure 2). As suggested by EDX analyses, the foams produced from the Fe-containing slurry consist of $\alpha-\mathrm{Fe}_{2} \mathrm{O}_{3}$. In contrast, the XRD of the foams produced from the FeMn-containing slurry indicate a mixture of $\alpha-\mathrm{Fe}_{2} \mathrm{O}_{3}, \mathrm{FeMnO}_{3}$ and $\mathrm{Fe}_{2} \mathrm{MnO}_{4}$ phases. Phase contributions and cell parameters estimated by Rietveld refinement are listed in Table 3. Sintering the FeMn-containing foams at higher $\mathrm{N}_{2}$ flow results in larger amounts of $\mathrm{Fe}_{2} \mathrm{MnO}_{4}$. As can be observed in Table 3, the amount of $\mathrm{Fe}_{2} \mathrm{MnO}_{4}$ increases from 8.5 to $74 \%$ when increasing the $\mathrm{N}_{2}$ flow from 180 to $650 \mathrm{~L} / \mathrm{h}$. Accordingly, the $\mathrm{Fe}_{2} \mathrm{O}_{3}$ phase percentage decreases from 60 to $26 \%$. $\mathrm{FeMnO}_{3}$ only forms at a $\mathrm{N}_{2}$ flow of $180 \mathrm{~L} / \mathrm{h}$.

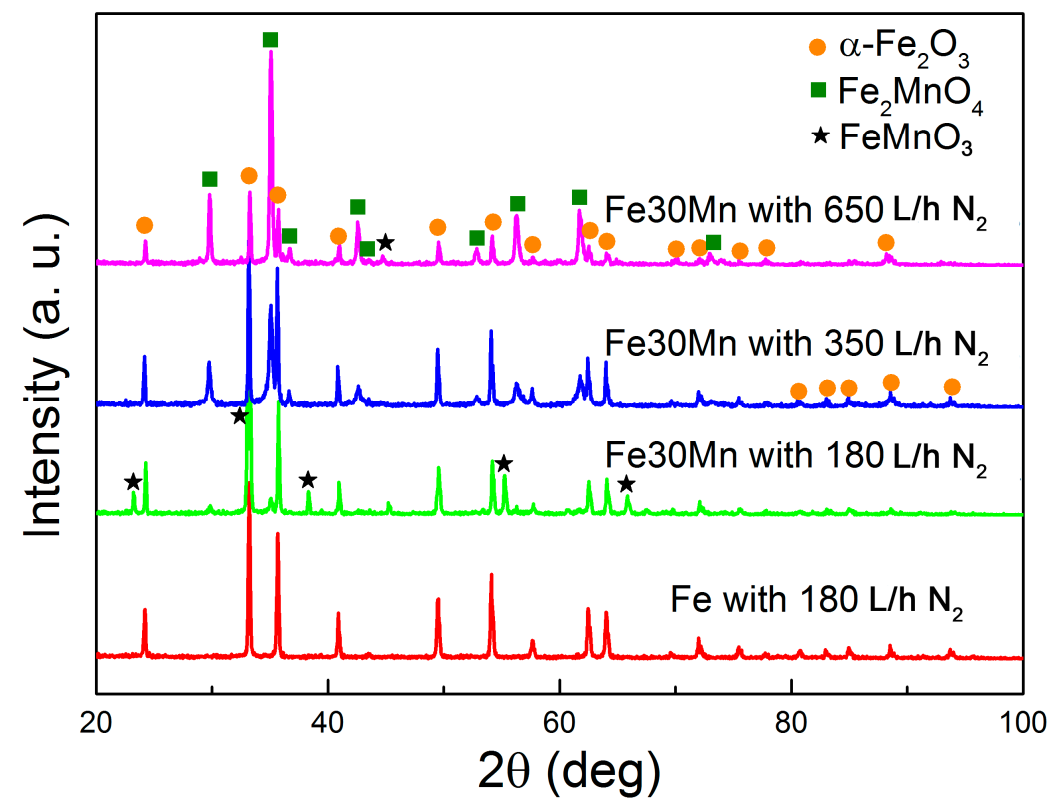

Figure 2. X-ray diffraction (XRD) patterns of the Fe-O foam produced at $\mathrm{N}_{2}$ flow of $180 \mathrm{~L} / \mathrm{h}$ and Fe-Mn-O foams produced at a $\mathrm{N}_{2}$ flow of $180 \mathrm{~L} / \mathrm{h}, 350 \mathrm{~L} / \mathrm{h}$ and $650 \mathrm{~L} / \mathrm{h}$. 
Table 3. Phase percentage and cell parameters ( $a$ and $c$ ) of the obtained foams.

\begin{tabular}{ccccc}
\hline Alloy & \multicolumn{2}{c}{ Phase } & Cell Parameters (Å) & $\%$ \\
\hline Fe-O $(180 \mathrm{~L} / \mathrm{h})$ & hematite & $\mathrm{Fe}_{2} \mathrm{O}_{3}$ & $a=5.036 ; c=13.748$ & 100 \\
\hline \multirow{2}{*}{ Fe-Mn-O (180 L/h) } & hematite & $\mathrm{Fe}_{2} \mathrm{O}_{3}$ & $a=5.038 ; c=13.741$ & 60 \\
& bixbyite & $\mathrm{FeMnO}_{3}$ & $a=9.417$ & 31.5 \\
& jacobsite & $\mathrm{Fe}_{2} \mathrm{MnO}_{4}$ & $a=8.489$ & 8.5 \\
\hline \multirow{2}{*}{ Fe-Mn-O (350 L/h) } & hematite & $\mathrm{Fe}_{2} \mathrm{O}_{3}$ & $a=5.036 ; c=13.741$ & 51 \\
& jacobsite & $\mathrm{Fe}_{2} \mathrm{MnO}_{4}$ & $a=8.483$ & 49 \\
\hline \multirow{2}{*}{ Fe-Mn-O (650 L/h) } & Hematite & $\mathrm{Fe}_{2} \mathrm{O}_{3}$ & $a=5.036 ; c=13.745$ & 26 \\
& jacobsite & $\mathrm{Fe}_{2} \mathrm{MnO}_{4}$ & $a=8.5028$ & 74 \\
\hline
\end{tabular}

\subsection{Magnetic Properties}

Figure 3 shows the hysteresis loops of the open-cell porous foams produced from the Fe- and FeMn-containing slurries at different nitrogen flow rates. A linear magnetization versus field behavior (reaching $0.6 \mathrm{emu} / \mathrm{g}$ for an applied field of $20 \mathrm{kOe}$ ) was observed in the Fe-O foams, in agreement with the reported behavior for antiferromagnetic $\alpha-\mathrm{Fe}_{2} \mathrm{O}_{3}$. Clear hysteresis loops are observed in the FeMn-containing foams as a result of the ferrimagnetic character of the $\mathrm{Fe}_{2} \mathrm{MnO}_{4}$ phase, which exhibits a theoretical saturation magnetization, $\mathrm{M}_{\mathrm{s}}$, of $77 \mathrm{emu} / \mathrm{g}$ at room temperature [31]. The $\mathrm{FeMnO}_{3}$ phase is known to exhibit a weakly ferrimagnetic response with $\mathrm{M}_{\mathrm{s}} \sim 0.23 \mathrm{emu} / \mathrm{g}$ [32]. Accordingly, the saturation magnetization of the FeMn-containing foams ranges from $5 \mathrm{emu} / \mathrm{g}$ to $52 \mathrm{emu} / \mathrm{g}$ depending on the $\mathrm{N}_{2}$ flow rate, i.e., the relative amount of $\mathrm{FeMnO}_{3}$ and $\mathrm{Fe}_{2} \mathrm{MnO}_{4}$ phases. For instance, an $\mathrm{M}_{\mathrm{S}}$ value of $37.7 \mathrm{emu} / \mathrm{g}$ would be expected for the foam produced under a $\mathrm{N}_{2}$ flow of $350 \mathrm{~L} / \mathrm{h}$ as it contains $49 \%$ of $\mathrm{Fe}_{2} \mathrm{MnO}_{4}$. The observed $\mathrm{M}_{\mathrm{s}}$ in this case $(40 \mathrm{emu} / \mathrm{g})$ is in quite good agreement with the expected value. The foam produced under a $\mathrm{N}_{2}$ flow of $650 \mathrm{~L} / \mathrm{h}$ has $\mathrm{M}_{\mathrm{S}}=52 \mathrm{emu} / \mathrm{g}$ which is also in good agreement with the theoretically calculated value $(57 \mathrm{emu} / \mathrm{g})$.

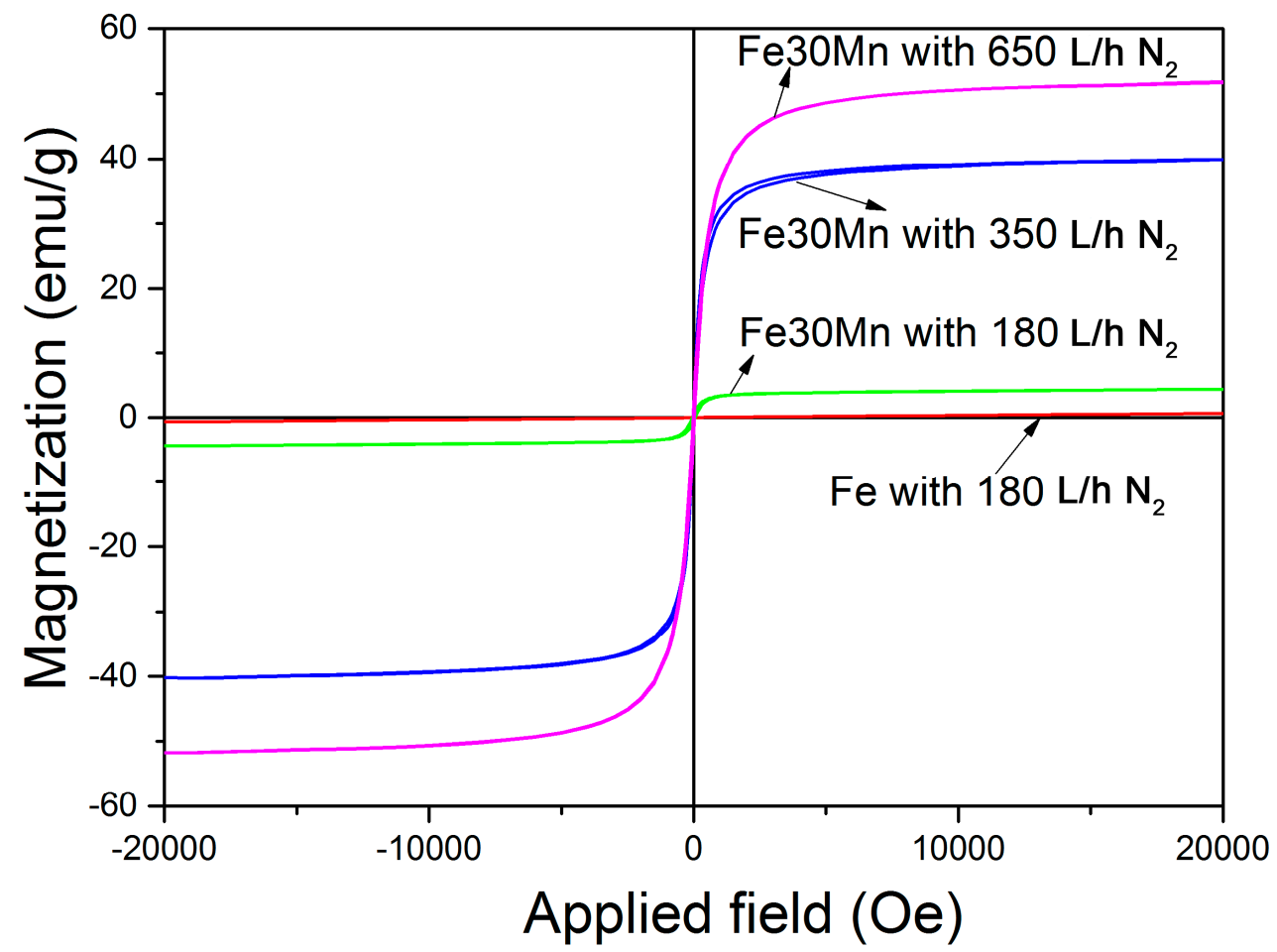

Figure 3. Room temperature hysteresis loops of four kinds of open-cell porous foams produced from the Fe- and FeMn-containing slurries at different nitrogen flow rate. 


\section{Conclusions}

Highly porous foams with homogeneous open-cell structure have been obtained by the replication process using polyurethane templates. The foams produced from the Fe-containing slurry consist of $\alpha-\mathrm{Fe}_{2} \mathrm{O}_{3}$, independently of the $\mathrm{N}_{2}$ flow. In contrast, the phase composition of the foams produced from the FeMn-containing slurry can be tuned by adjusting the $\mathrm{N}_{2}$ flow. The main phases of the Fe-Mn-O foams sintered under a $\mathrm{N}_{2}$ flow of $180 \mathrm{~L} / \mathrm{h}$ are $\alpha-\mathrm{Fe}_{2} \mathrm{O}_{3}$ and $\mathrm{FeMnO}_{3}$ with minor content of $\mathrm{Fe}_{2} \mathrm{MnO}_{4}$. Increasing the $\mathrm{N}_{2}$ flow to $350 \mathrm{~L} / \mathrm{h}$ results in a mixture of $\alpha-\mathrm{Fe}_{2} \mathrm{O}_{3}$ and $\mathrm{Fe}_{2} \mathrm{MnO}_{4}$. The amount of manganese ferrite is further increased at a flow rate of $650 \mathrm{~L} / \mathrm{h}$. Hence, addition of $\mathrm{Mn}$ as well as the adjustment of the $\mathrm{N}_{2}$ flow allows tailoring the magnetic response of the foams from practically non-magnetic to soft ferrimagnetic. The magnetic behavior reported in this work for the Fe30Mn foams obtained at a $\mathrm{N}_{2}$ flow rate of 350 and $650 \mathrm{~L} / \mathrm{h}$ could be of interest for a wide range of applications, such as electromagnetic absorbers, catalysts supports, thermal and acoustic insulation systems or wirelessly magnetically-guided porous objects in fluids.

Acknowledgments: This work has been partially funded by the 2017-SGR-292 project from the Generalitat de Catalunya, the MAT2014-57960-C3-1-R and MAT2017-86357-C3-1-R (co-financed by the Fondo Europeo de Desarrollo Regional, FEDER), from the Spanish Ministerio de Economía y Competitividad (MINECO) and the SPINPORICS 2014-Consolidator Grant (Agreement No. 648454) from the European Research Council. J.F. acknowledges the Juan de la Cierva Fellowship from MINECO (IJCI-2015-27030), E.P. is grateful to MINECO for the "Ramon y Cajal" contract (RYC-2012-10839) and Y.F. is grateful to the Chinese Scholarship Council for his PhD Grant.

Author Contributions: J.S. and J.F. conceived and designed the experiments; Y.F., S.S. and P.S. performed the experiments; E.P., J.F. and Y.F. analyzed the data; Y.F., J.F. and D.B. wrote the paper.

Conflicts of Interest: The authors declare no conflict of interest.

\section{References}

1. Seymour, R.B.; Kauffman, G.B. Polyurethanes: A Class of Modern Versatile Materials. J. Chem. Educ. 1992, 69, 909-910. [CrossRef]

2. Karl, S.; Somers, A.V. Method of Making Porous Ceramic Articles. U.S. Patent 3,090,094 A, 21 May 1963.

3. Park, K.Y.; Lee, S.E.; Kim, C.G.; Han, J.H. Fabrication and electromagnetic characteristics of electromagnetic wave absorbing sandwich structures. Compos. Sci. Technol. 2006, 66, 576-584. [CrossRef]

4. Chen, Z.P.; Xu, C.; Ma, C.Q.; Ren, W.C.; Cheng, H.M. Lightweight and flexible graphene foam composites for high-performance electromagnetic interference shielding. Adv. Mater. 2013, 25, 1296-1300. [CrossRef] [PubMed]

5. Yavari, F.; Chen, Z.P.; Thomas, A.V.; Ren, W.C.; Cheng, H.M.; Koratkar, N. High sensitivity gas detection using a macroscopic three-dimensional graphene foam network. Sci. Rep. 2011, 1. [CrossRef] [PubMed]

6. Buciuman, F.C.; Czarnetzki, B.K. Preparation and characterization of ceramic foam supported nanocrystalline zeolite catalysts. Catal. Today 2001, 69, 337-342. [CrossRef]

7. Chen, N.; Pan, Q. Versatile fabrication of ultralight magnetic foams and application for oil-water separation. ACS Nano 2013, 7, 6875-6883. [CrossRef] [PubMed]

8. Kang, E.; Jung, Y.S.; Cavanagh, A.S.; Kim, G.H.; George, S.M.; Dillon, A.C.; Kim, J.K.; Lee, J. $\mathrm{Fe}_{3} \mathrm{O}_{4}$ nanoparticles confined in mesocellular carbon foam for high performance anode materials for lithium-ion batteries. Adv. Funct. Mater. 2011, 21, 2430-2438. [CrossRef]

9. Williams, E.J.A.E.; Evans, J.R.G. Expanded ceramic foam. J. Mater. Sci. 1996, 31, 559-563. [CrossRef]

10. Wang, S.R.; Geng, H.R.; Hui, L.H.; Wang, Y.Z. Reticulated porous multiphase ceramics with improved compressive strength and fracture toughness. J. Mater. Eng. Perform. 2007, 16, 113-118. [CrossRef]

11. Bhaduri, S.B. Science and technology of ceramic foams. Adv. Perform. Mater. 1994, 1, 205-220. [CrossRef]

12. Arrance, F.C. Battery Electrode and Battery, and Process for Preparing Said Electrode. U.S. Patent 3,287,166 A, 22 November 1996.

13. Antsiferov, V.N.; Makarov, A.M.; Khramtsov, V.D. High-porosity permeable cellular metals and alloys in catalytic processes of gas cleaning. Adv. Eng. Mater. 2005, 7, 77-91. [CrossRef] 
14. Roesler, J.F. Application of polyurethane foam filters for respirable dust separation. J. Air. Pollut. Control Assoc. 1996, 16, 30-34. [CrossRef]

15. Haack, D.P.; Butcher, K.R.; Kim, T.; Lu, T.J. Novel Lightweight Metal Foam Heat Exchangers; Porvair Fuel Cell Technology, Inc.: Hendersonville, NC, USA, 2001.

16. Quadbeck, P.; Stephani, G.; Kümmel, K.; Adler, J.; Standke, G. Synthesis and properties of open-celled metal foams. Mater. Sci. Forum 2007, 534-536, 1005-1008. [CrossRef]

17. Quadbeck, P.; Kümmel, K.; Hauser, R.; Standke, G.; Adler, J.; Stephani, G. Open cell metal foams-application-oriented structure and material selection. In Proceedings of the International Conference on Cellular Materials, Dresden, Germany, 27-29 October 2010; pp. 279-288.

18. Quadbeck, P.; Kümmel, K.; Hauser, R.; Standke, G.; Adler, J.; Stephani, G.; Kieback, B. Structural and material design of open-cell powder metallurgical foams. Adv. Eng. Mater. 2011, 13, 1024-1030. [CrossRef]

19. Zhang, H.; Pinjala, D.; Joshi, Y.K.; Wong, T.N.; Toh, K.C.; Iyer, M.K. Fluid flow and heat transfer in liquid cooled foam heat sinks for electronic packages. IEEE Trans. Comp. Packag. Technol. 2005, 28, 272-280. [CrossRef]

20. Li, J.P.; Li, S.H.; Groot, K.D.; Layrolle, P. Improvement of porous titanium with thicker struts. Key Eng. Mater. 2003, 240-242, 547-550. [CrossRef]

21. Manonukul, A.; Tange, M.; Srikudvien, P. Rheological properties of commercially pure titanium slurry for metallic foam production using replica impregnation method. Powder Technol. 2014, 266, 129-134. [CrossRef]

22. Biswas, P.; Ramavath, P.; Nair, C.M.; Suresh, M.B.; Ravi, N.; Johnson, R. Quasi-static compression behavior of nickel oxide, nickel oxide: Zirconia, nickel:zirconia and nickel foams. Ceram. Int. 2016, 42, 10572-10578. [CrossRef]

23. Zuo, X.; Barbiellini, B.; Vittoria, C. Calculation of exchange constants in manganese ferrite $\left(\mathrm{MnFe}_{2} \mathrm{O}_{4}\right)$. J. Magn. Magn. Mater. 2004, 272, 306-311. [CrossRef]

24. Padella, F.; Alvani, C.; Barbera, A.L.; Ennas, G.; Liberatore, R.; Varsano, F. Mechanosynthesis and process characterization of nanostructured manganese ferrite. Mater. Chem. Phys. 2005, 90, 172-177. [CrossRef]

25. Durán, F.G.; Barbero, B.P.; Cadús, L.E.; Rojas, C.; Centeno, M.A.; Odriozola, J.A. Manganese and iron oxides as combustion catalysts of volatile organic compounds. Appl. Catal. B 2009, 92, 194-201. [CrossRef]

26. Quiroga, M.M.B.; Barbero, B.P.; Cadus, L.E. Synthesis of a catalyst of $\mathrm{Mn}-\mathrm{Fe}-\mathrm{O}$ by mechano-chemical reaction. Appl. Catal. A 2014, 474, 26-33. [CrossRef]

27. Mahmoud, M.H.; Hamdeh, H.H.; Ho, J.C.; O'shea, M.J.; Walker, J.C. Mössbauer studies of manganese ferrite fine particles processed by ball-milling. J. Magn. Magn. Mater. 2000, 220, 139-146. [CrossRef]

28. Amighian, J.; Mozaffari, M.; Nasr, B. Preparation of nano-sized manganese ferrite $\left(\mathrm{MnFe}_{2} \mathrm{O}_{4}\right)$ via coprecipitation method. Phys. Status Solidi C 2006, 3, 3188-3192. [CrossRef]

29. Baldi, M.; Escribano, V.S.; Amores, J.M.G.; Milella, F.; Busca, G. Characterization of manganese and iron oxides as combustion catalysts for propane and propene. Appl. Catal. B 1998, 17, L175-L182. [CrossRef]

30. Kwon, W.H.; Kang, J.Y.; Lee, J.G.; Lee, S.W.; Chae, K.P. Synthesis and magnetic properties of Zn, Co and Ni substituted manganese ferrite powders by sol-gel method. J. Magn. 2010, 15, 159-164. [CrossRef]

31. Rafique, M.Y.; Qing, P.L.; Javeb, Q.U.A.; Iqbal, M.Z.; Mei, Q.H.; Farooq, M.H.; Gang, G.Z.; Tanveer, M. Growth of monodisperse nanospheres of $\mathrm{MnFe}_{2} \mathrm{O}_{4}$ with enhanced magnetic and optical properties. Chin. Phys. B 2013, 22. [CrossRef]

32. Rayaprol, S.; Kaushik, S.D.; Babu, P.D.; Siruguri, V. Structure and magnetism of FeMnO 3 . AIP Conf. Proc. 2013, 1512, 1132-1133.

(C) 2018 by the authors. Licensee MDPI, Basel, Switzerland. This article is an open access article distributed under the terms and conditions of the Creative Commons Attribution (CC BY) license (http:// creativecommons.org/licenses/by/4.0/). 